\title{
Slugs as Pasture Pests
}

\author{
M.J. WILSON ${ }^{1}$ and G.M. BARKER ${ }^{2}$ \\ ${ }^{1}$ AgResearch, Ruakura Research Centre, Private Bag 3123, Hamilton 3240 \\ ${ }^{2}$ Landcare Research, Private Bag 3127, Hamilton 3240 \\ michael.wilson@agresearch.co.nz
}

\begin{abstract}
Several invasive European slug species are thriving in New Zealand and have become important pests of many crops. In pasture, they are particularly damaging to white clover during renovation and the problem may be exacerbated by direct drilling. Slug feeding causes both lethal and sublethal damage that reduces clover establishment and thus pasture quality. Much less is known about slug damage to established pastures and the degree to which slugs limit pasture persistence. Established pastures frequently support large slug populations that feed on clover and the application of molluscicides can reduce slug numbers and increase the proportion and yields of clover. Future research on these pests should concentrate on determining damage thresholds, breeding resistant clover varieties and developing agronomic practices that favour natural enemies. In the long term, there is much potential for developing microbiological pesticides that target slugs.
\end{abstract} Keywords: molluscs, slugs, clover

\section{Introduction}

Terrestrial molluscs (slugs and snails) are an extremely successful group of organisms that are widely distributed throughout the world, and in many cases, have established themselves as serious crop pests (Barker 2002a). While New Zealand has an extremely rich terrestrial mollusc fauna, the vast majority of indigenous species are confined to native forests, alpine areas and tussock grasslands. Conversely, in agricultural areas, the terrestrial mollusc fauna is dominated by a handful of invasive European slug species, particularly Deroceras reticulatum (the grey field slug), D. panormitanum, Arion distinctus, A. hortensis, A. intermedius, Milax gagates and Tandonia sowerbyi.

Slugs are interesting from an ecological perspective because they are extreme generalists in terms of feeding. For this reason, they are significant pests of a broad range of crops including arable crops, horticultural crops and ornamentals. In pasture, while slugs will feed on grasses, it is damage to clover and the consequent reduction in nitrogen fixation that is of most concern (Barker 2002b). Slug damage is particularly visible during pasture establishment, but established pasture may support high populations of slugs that are likely to influence pasture persistence.

\section{Slugs and pasture establishment}

Slugs are best known in New Zealand pastoral agriculture as pests of pasture establishment (Barker 1991). Pasture persistence is thought to be on the decline for various reasons (discussed in other papers in this volume), and the need to renew pastures is increasing. Thus, it is likely that this kind of slug damage may become a more common problem in the future. Clover is particularly susceptible during establishment, and slugs may reduce plant populations by either feeding on seeds or severing young shoots shortly after emergence. Slugs may also reduce plant vigour by removal of cotyledons and young leaves. While in monocultures of cereals or oilseed crops, plants can usually compensate for such sublethal slug damage, in the competitive situation of clover/ryegrass swards, sublethal damage to clover can lead to establishment failure.

Several factors will increase the tendency of slugs to impair pasture establishment. Slug population growth is often limited by water availability, thus high rainfall areas and clay soils are both associated with increased slug populations. The method of establishment is also of great importance. Cultivation prior to sowing tends to kill many slugs, and slugs are only a problem in such systems in heavy soils with cloddy seedbeds. If pastures are direct drilled or oversown, seeds and emerging seedlings may be exposed to high slug population densities and feeding pressure. In such circumstances some farmers choose to protect plants from slug damage using molluscicidal baits (slug pellets). Such baits contain one of a range of active ingredients with methiocarb and metaldehyde being most common. However, if good practice is followed during establishment, slug damage can be minimised without resorting to the use of molluscicides. Such good practice includes the use of intensive grazing (Ferguson et al. 1989) or heavy rolling after drilling that kills many slugs and increases seed/soil contact and hence plant vigour. Sowing new pasture in autumn, when mollusc populations tend to be low, is also good practice. 


\section{Slugs and pasture persistence}

Much less is known about slug damage to established pasture and the role of slugs in limiting pasture persistence. It is clear that pastures can support large numbers of slugs and that clover in such pastures often show signs of defoliation typical of that caused by slugs. Barker \& Addison (1992) treated established pasture with molluscicidal baits which reduced numbers of slugs, and also increased the yield of clover by $12-40 \%$. It is difficult to determine whether such increases would be cost effective, as the benefits of clover in relation to increased milk yield and nitrogen fixation are difficult to quantify. However, damage at the higher levels observed by Barker \& Addison (1992) would clearly influence the persistence of clover in pasture, which when combined with damage caused by other pests (see below) is likely to necessitate pasture renewal.

At present, no active interventions are directed at controlling slugs in established pasture, but high stocking rates and rotational grazing can help to reduce slug populations.

\section{Slugs as part of a clover pest complex}

It should be emphasised that slugs rarely damage pasture in the absence of other pests, including a range of insects and nematodes. The relative importance of individual pests will vary considerably according to climatic, soil and agronomic factors and it is likely that the combined pressure from all pests together is what will influence plant survival. In addition, the damage done, and loss of yield caused by the pest complex will be influenced by the relative health of the plants. If the plants are under stress, e.g. from drought or low $\mathrm{P}$ availability, then clover is less able to compensate for pest damage, and can even be eliminated from the sward. Conversely, in a fertile soil situation with ample water, competition between grasses and clover is intense and pest damage can severely disrupt the balance between grasses and clover. Pest damage to clover can lead to grass dominance (Barker 2002b).

Improving communication among scientists who specialise in grazing systems, agronomy, soil fertility and pests is needed to increase our understanding of how invertebrates influence both pasture establishment and persistence. In addition, such increased communication will identify areas where our knowledge is lacking and hence determine research priorities.

\section{Future potential for increased importance of slugs}

Agriculture is a constantly changing endeavour and changes in land use reflect changes in market forces and increasingly, changes in climate. In recent years the area of dairy farming and the use of irrigation has increased in parts of New Zealand. In particular there has been a change of emphasis from arable to dairy in Canterbury and from sheep farming to dairy in many regions of New Zealand. Slug damage was previously rare in these regions; however, farmers are now reporting slug problems on the new dairy conversions. Any changes in climate that increase precipitation are likely to make dairy farming a more viable option, but this too will encourage slug problems.

\section{Future control methods and research needs}

In the immediate future, it would be beneficial to determine the slug population thresholds during establishment at which molluscicide application would bring a significant cost benefit. This would build on the work of Fergusson \& Barratt (1983) but would need to be combined with developing a simple method for growers to determine slug numbers. In the longer term, more effective, sustainable management techniques are needed to control slugs in pasture and many other crops.

Worldwide, slugs cause millions of dollars of damage per year to a wide variety of crops. While losses to individual growers can be substantial, values of losses in key industry sectors are trivial compared with those caused by insect and nematode pests, fungi and weeds. Consequently, the agrochemical industries do not have discovery programmes targeted at finding new active ingredients for molluses and it is unlikely slug problems will be solved by novel chemical methods. It may be possible to decrease the effect of slugs during pasture establishment by developing existing molluscicides as seed treatments. This approach has met with some success in cereals, ryegrass and oilseed rape (Canola) (Ester \& Nijënstein 1996; Simms et al. 2002), but there is no evidence of uptake by the pasture seeds industry so far.

Plant breeding for slug-resistant clover varieties may also offer a solution, but as with development of new active ingredients, breeding programmes are driven by multiple outcomes of which slug resistance does not rank highly. When offered a choice of plants, slugs favour acyanogenic clover varieties over cyanogenic ones (Angseesing 1974) and to this end, white clover in New Zealand is predominantly cyanogenic (Caradus et al. 1989). However, work by Burgess \& Ennos (1987) suggests that in pasture systems in which acyanogenic plants are rare (i.e., slugs have little choice), the protection offered by cyanogenesis is likely to be low.

Many natural enemies of invasive slugs are present in New Zealand, including microsporidia, protozoa, parasitic nematodes and predatory beetles and they are likely to exert some control on slug populations (Barker 2002b). Pasture husbandry practices that 
encourage abundance and diversity of natural enemies could be useful, especially since such measures will also encourage natural enemies of other members of the pest complex.

There is also much potential for developing biopesticides for slugs. Little work has been done studying diseases of slugs. In Europe, a nematode parasite, Phasmarhabditis hermaphrodita is on sale in several countries as a biological molluscicide (Rae et al. 2007). The product is particularly effective against $D$. reticulatum but its high price means that even if this nematode is found to occur in New Zealand, products would be prohibitively expensive for use on pasture. Mass production of microbial products, particularly bacteria is much cheaper, and bacterial products are already sold to control grass grub in pasture. Current work at AgResearch aims to identify bacteria with potential for development as molluscicides for use in pasture and other systems (Howlett et al. 2009).

\section{REFERENCES}

Angseesing, J.P.A. 1974. Selective eating of the acyanogenic form of Trifolium repens. Heredity 32: 73-83.

Barker, G.M. 1991. Slug density-seedling establishment relationships in a pasture renovated by direct drilling. Grass and Forage Science 46: 113-120.

Barker, G.M. 2002a. Molluscs as crop pest. CABI Publishing, Wallingford. 468pp.

Barker, G.M. 2002b. Gastropods as pests in New Zealand pastoral agriculture, with emphasis on Agriolimacidae, Arionidae and Milacidae. pp. 361423 In: Barker GM (ed.), Molluses as crop pests. Wallingford, CAB International.

Barker, G.M.; Addison, P.J. 1992. Pest status of slugs (Stylommatophora: Mollusca) in two New Zealand pastures. Crop Protection 11: 439-442.
Burgess, R.S.L.; Ennos, R.A. 1987. Selective grazing of acyanogenic white clover: variation in behaviour among populations of the slug Deroceras reticulatum. Oecologia 73: 432-435.

Caradus, J.R.; McKay, A.C.; Woodfield, D.R.; van der Bisch, J.; Wewala, S. 1989. Classification of a world collection of white clover cultivars. Euphytica 42: 42-49.

Ester, A.; Nijënstein, J.H. 1996. Molluscicidal seed treatment of barley, wheat and perennial ryegrass to control the field slug (Deroceras reticulatum). Netherlands Journal of Agricultural Science 44: 241-248.

Ferguson, C.; Barratt. B.I.P. 1983. Slug damage to pasture renovated by direct drilling. pp 212-215. In: Proceedings of the $36^{\text {th }}$ New Zealand Weed and Pest Control Conference.

Ferguson, C.; Barratt, B.I.P.; Jones, P.A. 1989. Control of the grey field slug (Deroceras reticulatum (Müller)) by stock management prior to directdrilled pasture establishment. Journal of Agricultural Science 111: 443-449.

Howlett, S.A.; Burch, G.; Sarathchandra, U.; Bell, N.L 2009. A bioassay technique to assess the molluscicidal effects of microbes. New Zealand Plant Protection 64: 7-11.

Rae, R.G.; Verdun, C.; Grewal, P.S.; Robertson, J.F.; Wilson, M.J. 2007. Biological control of terrestrial molluscs using Phasmarhabditis hermaphrodita progress and prospects. Pest Management Science 63: 1153-1164.

Simms, L.C.; Mullins, C.E.; Wilson, M.J. 2002. Seed dressings to control slug damage in oilseed rape. Pest Management Science 58: 687-694. 
